\title{
Lumbar Microdiscectomy Under Spinal and General Anesthesia: A Comparative Study
}

\author{
Spinal ve Genel Anestezi Altunda Lomber Mikrodiskektomi: \\ Karşılaştırmalı Bir Çalışma
}

\author{
Yasar DAGISTAN ${ }^{1}$, Korgun OKMEN² ${ }^{2}$ Emine DAGISTAN ${ }^{3}$, Ali GULER ${ }^{4}$, Nezih OZKAN ${ }^{1}$

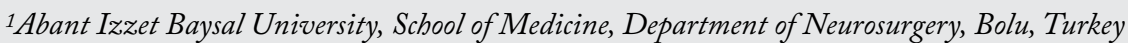 \\ ${ }^{2}$ Izzet Baysal Hospital, Department of Anesthesiology, Bolu, Turkey \\ ${ }^{3}$ Abant Izzet Baysal University, School of Medicine, Department of Radiology, Bolu, Turkey \\ ${ }^{4}$ Derince Training and Research Hospital, Department of Neurosurgery, Kocaeli, Turkey
}

Corresponding Author: Yasar DAGISTAN / E-mail: dagistanyasar@hotmail.com

\begin{abstract}
AIM: To compare the safety and efficacy of spinal anesthesia (SA) in patients undergoing lumbar microdiscectomy (LM).

MATERIAL and METHODS: We evaluated 180 patients who underwent LM between 1 January 2012 and 5 July 2013. Demographic, clinical, laboratory, and pre-, intra-, and postoperative information was determined from the patients' medical records.

RESULTS: Total anesthetic times were longer in the general anesthesia (GA) group. There was less bleeding at the surgical site in the SA group. Intraoperative blood pressure was significantly also lower in the SA group. Meanwhile, tachycardia was significantly higher in the GA group. The analgesic requirement in post-anesthesia care unit (PACU) was higher in the general anesthesia group. At PACU admission, analgesic requirement, heart rate, and the mean arterial pressure were higher in the GA group. Postoperative nausea and vomiting was more frequent among patients recovering in general anesthesia group. SA patients had an increased incidence of urinary retention compared with GA patients. Pulmonary complications requiring specific treatment were insignificantly higher among GA patients.

CONCLUSION: In patients who undergo lumbar disc surgery, SA is a good alternative for experienced surgeons because of a more comfortable healing process.
\end{abstract}

KEYWORDS: Lumbar disk herniation, Lumbar microdiscectomy, Spinal anesthesia, General anesthesia

öz

AMAÇ: Lomber mikrodiskektomi (LM) uygulanan hastalarda spinal anestezi (SA) güvenirliğini ve etkinliğini karşılaştırmaktır.

YÖNTEM ve GEREÇLER: 1 Ocak 2012 ve 5 Temmuz 2013 tarihleri arasında LM uygulanan 180 hastanın demografik, klinik, laboratuvar, pre-, intra-, postoperatif bilgileri tıbbi kayıtlarından elde edilerek değerlendirildi.

BULGULAR: Total anestezi zamanı genel anestezide (GA) daha uzundu. SA grubunda operasyon alanında kanama daha az idi. Intraoperatif kan basıncı SA grubunda anlamlı derecede düşük bulundu. Buna karşın, taşikardi GA grubunda anlamlı olarak daha yüksekti. Anestezi sonrası bakım ünitesinde (PACU) analjezik gereksinimi, GA grubunda daha yüksek idi. PACU kabulde, analjezik gereksinimi, kalp atım hızı ve ortalama arter basıncı GA grubunda yüksek bulundu. Postoperatif bulantı ve kusma GA grubunda daha sık oldu. SA hastalar GA hastalarla karşılaştırıldığında idrar retansiyonu görülme sıklığı arttı. Spesifik tedavi gerektiren pulmoner komplikasyonlar GA hastalarında önemli olmamakla beraber yüksek bulundu.

SONUÇ: SA altında lomber disk cerrahisi uygulaması hastalar için daha konforlu bir iyileşme süreci geçirilmesine neden olduğundan dolayı deneyimli cerrahlar için iyi bir seçenektir.

ANAHTAR SÖZCÜKLER: Lomber disk hernisi, Lomber mikrodiskektomi, Spinal anestezi, General anestezi

\section{INTRODUCTION}

Lumbar microdiscectomy (LM) is one of the most common spinal procedures, and is usually performed under general anesthesia (GA) (18). However, spinal anesthesia (SA) provides a safe and highly satisfactory alternative to general anesthesia in patients undergoing limited lumbar surgery (17). There is an increased risk of cardiac, respiratory, renal complications together with increasing age, duration of surgery and the use of general anesthetic as in cases undergoing high-risk colorectal surgery (26). In contrast, the risk associated with spinal anesthesia (SA) is rare and generally minor (25). In addition, SA may reduce the length of hospital stays and overall costs (18).

In general, SA has been shown to carry a very low risk of serious complications. Reports of serious complications occurring when spinal anesthesia is applied in lumbar surgery are also rare, but have still stirred concerns about the technique $(3$, 9). General endotracheal, spinal, and epidural anesthesia has been studied with respect to lumbar spine surgery. 
Insufficient data have been provided in the literature concerning the comparative study of SA and GA in patients who have undergone LM. The aim of this study was to compare the safety and efficacy of the intraoperative parameters and postoperative outcomes associated with SA and $G A$ in patients undergoing LM surgery.

\section{MATERIAL and METHODS}

The present analysis was a retrospective cross-sectional study. We evaluated 180 patients who underwent LM between 1 January 2012 and 5 July 2013 at the Department of Neurosurgery, Izzet Baysal State Hospital (Bolu, Turkey). The approval of the hospital management was obtained. Demographic, clinical, laboratory, and pre-, intra-, and postoperative information was determined from the patients' medical records. Patients with (1) prior lumbar surgery, (2) no protected airway (due to issues such as morbid obesity, sleep apnea), (3) local infection, or (4) coagulopathy were excluded from the analysis.

Patients were positioned in the prone position with their head turned to one side, and those anesthetized with SA were asked if they were "comfortable" before the induction of sedation. An anesthesiologist administered all the spinal and general anesthesia procedures. Patients within each group were anesthetized using a similar method. The 90 patients receiving $G A$ were induced with propofol ( $2 \mathrm{mg} / \mathrm{kg}$ ), fentanyl (5 mg/kg), and vecuronium $0.1 \mathrm{mg} / \mathrm{kg}$. Meanwhile, $\mathrm{N}_{2} \mathrm{O} / \mathrm{O}_{2}$ (2:1), isoflurane (0.3\%) and fentanyl $1.2 \mathrm{mg} / \mathrm{kg} / \mathrm{hour}$ were used for maintenance of anesthesia. The 90 patients receiving SA were induced with a single injection at the L3-4 intervertebral disk space via a Quincke 25-gauge spinal needle and injection of $3 \mathrm{~mL} 0.75 \%$ bupivacaine $8.5 \%$ dextrose solution in the subarachnoid space. During the operation, the patients were sedated with the required propofol infusion at 25 to 50 $\mu \mathrm{g} /(\mathrm{kg} \mathrm{min})$ i.v. On completion of the operation, propofol was discontinued, and the patient was rolled to the supine position.

All discectomies were performed by the same surgeon in the records. The patients underwent typical one- or twolevel microdiscectomy; no patient had a radical excision of the disc involving curettage of the disc space. In all patients, postoperative pain was controlled with parenteral analgesics for 24 hours. The postoperative rehabilitation protocol included walking within 6-8 hours after the operation, stretching exercises in 10 days, returning to work in 6 to 8 weeks, and permission for sports in 4 to 6 months in the GA group. In the SA group, most patients did not require postoperative analgesics, but their mobilization was later than that of the GA group.

\section{Statistical Analysis}

Statistical analysis was performed using IBM SPSS ver. 17.0 (IBM Co., Armonk, NY, USA). Demographic and clinical variables were compared among the groups using the Chi-square and independent $t$-tests. A $P$-value $<0.05$ was considered statistically significant.

\section{RESULTS}

The study population consisted of 180 patients (Tables I, II). Demographic and clinical characteristics of the patients in the SA and GA groups are summarized in Table III. There were no statistically significant differences between the two groups with respect to age, gender, preoperative heart rate, preoperative mean arterial pressure, or level of herniation. Total anesthetic times were longer in the GA group compared with the SA group $(p<0.01)$. There were no episodes of excessive hemorrhage in either group, and no patient required transfusion either for acute blood loss or hemodynamic instability. However, there was less bleeding at the incision site in the SA group. Intraoperative blood pressure was significantly also lower in the SA group $(p<0.0001)$. Meanwhile, tachycardia was significantly higher in the GA group $(\mathrm{p}<0.0001)$.

Early complications postoperative for SA group and GA group were showed in Table IV. The analgesic requirement in post-anesthesia care unit (PACU) was higher in the general anesthesia group than the spinal group. CSF fistula from puncture site occurred in 5 patients during surgery. However, postoperative problems did not occur.

At PACU admission, analgesic requirement, heart rate, and the mean arterial pressure (MAP) were higher in the GA group compared with the SA group (respectively, $p<0.0001$, $p<0.002$ ). Postoperative nausea and vomiting was more frequent among patients recovering in general anesthesia group $(p<0.0001)$. There was no neurological deficit in either group. SA patients had an increased incidence of urinary retention compared with GA patients $(p<0.0001)$. Pulmonary complications requiring specific treatment were insignificantly higher among GA patients compared with SA. The rates of early complications such as discitis, ileus, wound infection, and phlebitis rate were similar in the two groups.

\section{DISCUSSION}

The main findings of the present study were that anesthesia duration, nausea and vomiting, analgesic requirements, and complications were significantly lower in patients in the SA group compared with GA group. SA is a technique that reduces intraoperative bleeding, supplies perioperative hemodynamic stability, and reduces postoperative pain. Moreover, it reduces nausea, emesis, and thromboembolic complications. In particular, it prevents the neurological complications related to the prone position in GA. Postoperative pain control and other benefits show that $\mathrm{SA}$ is a useful technique for lumber surgery and should be preferred above GA (4, 5, 12, 14, 21). The type of anesthesia with patients before surgery was discussed and the patient was allowed to choose. There were a few nervous and excited cases among patients with spinal anesthesia. In these patients, mild sedation was adequate.

Ledowski et al. (15) indicated that mucociliary clearance can be damaged under GA; because of this, secretions can increase and atelectasis and infection in the down respiratory tract may develop. Moreover, Papadopoulos et al. (20), 
Table I: Level of Herniation of Patients Receiving Spinal Anesthesia

\begin{tabular}{|l|c|c|}
\hline Level of herniation & Number & $\%$ \\
\hline L3-L4 & 6 & 7 \\
\hline L4-L5 & 47 & 53 \\
\hline L5-S1 & 37 & 41 \\
\hline Total & 90 & 100.0 \\
\hline
\end{tabular}

Table II: Level of Herniation of Patients Receiving General Anesthesia

\begin{tabular}{|l|c|c|}
\hline Level of herniation & Number & $\%$ \\
\hline L3-L4 & 4 & 4 \\
\hline L4-L5 & 50 & 56 \\
\hline L5-S1 & 36 & 40 \\
\hline Total & 90 & 100.0 \\
\hline
\end{tabular}

compared SA and GA in 43 patients in whom LM was planned. They indicated that there was less vomiting in the epidural anesthesia group, and therefore that SA is a good alternative to GA. In the present study, vomiting was significantly higher in patients with GA. Even if not significantly so, pneumonia and atelectasis are more common in the GA group. Sadrolsadat et al. (24) compared spinal and general anesthesia in lumbar disc surgery, and reported less bleeding under SA and more complications in GA patients. In our study, we observed less bleeding complications and better bleeding control in SA patients. It can be said that this occurred because MAP is less in the SA group than the GA group.

The limited time for SA can narrow the time of the surgery. When SA duration is insufficient for the completion of surgery, an additional local anesthetic agent may be needed in the epidural or intradural spaces. Headache and urinary retention are the postoperative complications of SA. The blockage of S2-S4 roots with the local anesthetic reduces bladder tonus and inhibits miction reflexes. Patients must be followed for

Table III: Demographic Characteristics and Intraoperative Data for SA vs GA

\begin{tabular}{|l|c|c|c|}
\hline & GA $(\mathbf{n}=90)$ & SA $(\mathbf{n = 9 0})$ & NS \\
\hline Gender (male:female, \%) & $67: 33$ & $61: 39$ & NS \\
\hline Age (median, yr) & 38.0 & 42.0 & 0.010 \\
\hline Total anesthesia time (min) & $121 \pm 6.6$ & $83 \pm 6.3$ & NS \\
\hline Operation time (min) & $85 \pm 15$ & $71 \pm 12$ & NS \\
\hline Blood loss (mL) & $275 \pm 8.8$ & $246 \pm 8.4$ & 0.0001 \\
\hline Hypotension & $7(6 \%)$ & $23(25 \%)$ & NS \\
\hline Bradycardia & $6(7 \%)$ & $12(13 \%)$ & 0.0001 \\
\hline Tachycardia & $29(32 \%)$ & $6(7 \%)$ & NS \\
\hline IV fluid $(\mathrm{mL})$ & $2935 \pm 210$ & $2890 \pm 220$ & \\
\hline
\end{tabular}

GA: general anesthesia; SA: spinal anesthesia; NS: nonsignificant.

Table IV: Early Postoperative Complications for SA vs GA

\begin{tabular}{|c|c|c|c|}
\hline & GA $(n=90)$ & SA $(n=90)$ & $\mathbf{p}$ \\
\hline $\begin{array}{l}\text { In PACU } \\
\text { Analgesic requirement } \\
\text { Heart rate and MAP } \\
\text { Nausea and Vomiting }\end{array}$ & $\begin{array}{l}60(67 \%) \\
21(23 \%) \\
31(34 \%)\end{array}$ & $\begin{array}{c}14(15 \%) \\
7(8 \%) \\
5(6 \%)\end{array}$ & $\begin{array}{l}0.0001 \\
0.002 \\
0.0001\end{array}$ \\
\hline Urinary retention & $7(8 \%)$ & $23(25 \%)$ & 0.0001 \\
\hline Neurologic deficit & 0 & 0 & NS \\
\hline Pneumonitis or atelectasis & $5(6 \%)$ & $1(2 \%)$ & NS \\
\hline Phlebitis & 0 & 0 & NS \\
\hline Discitis & $3(3 \%)$ & $1(2 \%)$ & NS \\
\hline Defecation/ Flatus after $24 \mathrm{~h}$ & $5(6 \%)$ & 0 & NS \\
\hline $\begin{array}{l}\text { Wound problems } \\
\text { Hematoma } \\
\text { Infection } \\
\text { CSF fistula }\end{array}$ & $\begin{array}{l}0 \\
2(3 \%) \\
0\end{array}$ & $\begin{array}{l}0 \\
1(2 \%) \\
0\end{array}$ & $\begin{array}{l}\text { NS } \\
\text { NS } \\
\text { NS }\end{array}$ \\
\hline CSF fistula puncture site & 0 & $5(6 \%)$ & NS \\
\hline
\end{tabular}

MAP: mean arterial pressure; PACU: postanesthesia care unit; GA: general anesthesia; SA: spinal anesthesia; NS: nonsignificant. 
miction if a postoperative catheter is not used. Continuing urinary dysfunction may be the result of neurological damage (6). In the present study, patients under SA did not need additional anesthesia. Additionally, urinary retention occurred in four patients. However, the problem was resolved with the help of a temporary catheter. Additionally, we have preferred spinal anesthesia instead of epidural anesthesia. Epidural anesthesia has disadvantages such as more drug dose, an indwelling catheter, longer onset of analgesia, the piercing of the spinal cord, inadequate neuromuscular block.

Some problems can occur in lumbar microdiscectomy patients because of position. Nerve ischemia occurs because of tension and direct pressure on the ulnar, median, radial, brachial plexus, and axillary nerve; peripheral nerve damage is more likely occur more under GA than $S A(7,16,29)$. Moreover, damage to the lingual, buccal, and supraorbital nerve, phrenic nerve damage due to extension and rotation of neck, damage to the dorsal nerve of the penis, and recurrent laryngeal nerve damage have also been reported $(11,23,30,31)$. In addition, in the prone position under GA, face, ear, breast, and genital injuries can occur, as well as skin necrosis (1,22-28). In another study, periorbital edema, puffiness in the lips, and contact dermatitis in the face have been mentioned as associated with the prone position in GA (13). Muscles are relaxed under GA in the prone position, such that shoulder and cervical dislocations have been mentioned $(2,27)$. In addition, optic neuropathy and blindness have been reported $(8,10)$. However, we did not observe any neurological complication in GA patients in terms of intraoperative positioning.

Others have found SA to be safe and effective. Silver et al. used spinal anesthesia at Hartford Hospital for more than 9,000 disc operations over a 35-year period (25). They reported the results from a sample of this patient population. Of the 611 procedures studied, 576 were performed under spinal and 35 under general anesthesia. The single serious complication did not seem attributable to the choice of anesthetic method. Minor neurological complications, with the exception of spinal headache, could be explained by surgical manipulation. The authors concluded that SA is safe for surgical operations on lumbar discs. In another work, McLain et al. presented a case-controlled, comparative study of 400 patients undergoing lumbar surgery who were treated with either spinal or general anesthesia (17). In their study, overall complication rates and time to discharge were significantly lower in SA patients. Moreover, total anesthetic and operative times were significantly longer for GA patients. In addition, perioperative heart rates and mean arterial pressures were higher in GA than in SA patients. Significantly more GA patients experienced nausea requiring antiemetic medication and urinary retention. SA patients had fewer spinal headaches but statistical significance was not supplied. The researchers suggested that $S A$ is at least comparable with GA in terms of safety and efficacy, and that it may be superior to $G A$ in some ways.

Sadrolsadat et al. enrolled 100 patients in their study, all of which were awaiting laminectomy for herniated lumbar disks at 1 to 2 levels (24). The researchers reported that in patients administered SA, there was a lower prevalence of nausea and vomiting in the following day of the surgery, shorter recovery time, and lower need for analgesics during the recovery period. The patients in the GA group were reported to have intraoperative hypotension, as well as nausea and vomiting (in the recovery room), less frequently than the other group. The surgeons were also more satisfied with this method. They concluded that each method has its own preferred characteristics and did not support SA as the preferred method. Hassi et al. reported on 77 cases of spinal anesthesia in a 9-month period for lumbar laminectomy or herniated disc surgeries in the knee-chest posture (9). They found that operating conditions were good or excellent in 66 patients $(85.7 \%)$. No intra- or postoperative complications other than six cases of transient hypotension occurred. The researchers suggested that instead of having definite advantages, SA cannot be recommended in all cases, especially in long surgery times. Moreover, it should be mentioned to patients that GA is an option. In addition to all these, after spinal anesthesia, muscle test for extensor hallucis longus (EHL) cannot be done during 4-5 hours. Therefore, EHL test can be done after this time.

In another study, McLain et al. presented the current anesthetic technique for patients undergoing microdiscectomy and compared the peri- and postoperative outcomes in 76 patients drawn from a case-controlled study group (17). Patients underwent microdiscectomy under spinal (43 patients) or general anesthesia (33 patients). The researchers demonstrated that SA patients needed less analgesic treatment and showed less nausea and emesis. Moreover, in young and fit patients, SA supplied specific advantages over GA, including decreased anesthesia time, decreased nausea and antiemetic requirements, reduced analgesic requirements, fewer complications, and shorter hospital stays. Thus, surgeon and patient satisfaction with SA is high.

Dagher et al. investigated the amount of analgesia and recovery in LM surgery after SA compared to GA. Following light sedation, they performed SA in patients in the left lateral decubitus position, one to two levels above the herniated disc level (3). They have found that in the SA group, pain scores at 4 and $8 \mathrm{~h}$ and analgesic needs were lower. Time to eating, drinking, and walking was more rapid in SA compared to GA. After the postoperative period, urinary retention was similar between groups but the incidence of nausea and vomiting was significantly higher in the GA group. Moreover, patient and surgeon satisfaction was higher in the SA group (3). In our study, we found that there are significant advantages to spinal anesthesia compared to general anesthesia. Operation and total anesthetic times were shorter for the SA group. Moreover, postoperative nausea and emesis were more frequent among patients in the GA group recovering in PACU, while the number of patients with pain requiring analgesics was lower in the SA group. At PACU admission, heart rate and MAP were higher in the general group compared with the spinal group. SA patients had an increased incidence 
of urinary retention compared with GA patients. As further forward, spinal anesthesia advantages include patients selfpositioning, less distention of the epidural veins providing an excellent surgical field, establish a dialogue with the surgeon's patients facilitating decompression. However, experience shows the prolonged operation performed in the prone position under spinal anesthesia increase the surgeon's stress and anxiety. Limitation of SA may be L3-L4 level patients. In these patients may need to increase the dose of spinal anesthesia. We believe that spinal anesthesia is appropriate in such cases pure discectomy, primary discectomy, recurrent, stenosis and deformity.

In conclusion, in patients who undergo lumbar disc surgery, $\mathrm{SA}$ is a good alternative for experienced surgeons. This is because of the side effects of GA mentioned above, as well as the absence of nausea, vomiting, and postoperative pain in SA. Thus, post-operative patients experience a more comfortable healing process when SA has been used.

\section{REFERENCES}

1. Anderton JM: The prone position for the surgical patient: $A$ historical review of the principles and hazards. $\mathrm{Br} J$ Anaesth 67: 452-463, 1991

2. Chen SH, Hui YL, Yu CM, Niu CC, Lui PW: Paraplegia by acute cervical disc protrusion after lumbar spine surgery. Chang Gung Med J 28: 254-257, 2005

3. Dagher C, Naccache N, Narchi P, Hage P, Antakly MC: Regional anesthesia for lumbar microdiscectomy. J Med Liban 50: 206-210, 2002

4. Fassoulaki A, Petropoulos G, Staikou C, Siafaka I, Sarantopoulos C: General versus neuraxial anaesthesia for caesarean section: Impact on the duration of hospital stay. J Obstet Gynaecol 29:25-30, 2009

5. Freise $H$, Van Aken HK: Risks and benefits of thoracic epidural anaesthesia. Br J Anaesth 107:859-868, 2011

6. Gauss A, Jahn SK, Eberhart LH, Stahl W, Rockemann M, Georgieff M, Wagner F, Meierhenrich R: Cardioprotection by thoracic epidural anesthesia? Meta-analysis. Anaesthesist 60:950-962, 2011

7. Gwinnutt $C L$ : Injury to the axillary nerve (erratum appears in Anaesthesia 43: 529, 1988). Anaesthesia 43: 205-206, 1988

8. Halfon MJ, Bonardo P, Valiensi S, Zaffaroni MC, Fernandez Pardal MM, Ribero Ayerza D, Ebner R, Anderson P, Reisin RC: Central retinal artery occlusion and ophthalmoplegia following spinal surgery. Br J Ophthalmol 88:1350-1352, 2004

9. Hassi N, Badaoui R, Cagny-Bellet A, Sifeddine S, Ossart M: Spinal anesthesia for disk herniation and lumbar laminectomy. Apropos of 77 cases. Cah Anesthesiol 43:21-25, 1995

10. Ho VTG, Newman NJ, Song S, Ksiazek S, Roth S: Ischemic optic neuropathy following spine surgery. J Neurosurg Anesthesiol 17: 38-44, 2005

11. Hofmann A, Jones RE, Schoenvogel R: Pudendal-nerve neurapraxia as a result of traction on the fracture table. A report of four cases. J Bone Joint Surg Am 64: 136-138, 1982

12. Jellis WS, Shea JF: Spinal anesthesia for spinal surgery. Best Pract Res Anaesthesiol 17: 323-334, 2003

13. Jericho BG, Skaria GP: Contact dermatitis after the use of the PronePositioner. Anesth Analg 97:1706-1708, 2003
14. Kozian A, Schilling T, Hachenberg T: Non-analgetic effects of thoracic epidural anaesthesia. Curr Opin Anaesthesiol 18: 29-34, 2005

15. Ledowski T, Manopas A, Lauer S: Bronchial mucus transport velocity in patients receiving desflurane and fentanyl vs. sevoflurane and fentanyl. Eur J Anaesthesiol 25:752-755, 2008

16. Mahla ME, Long DM, McKennett J, Green C, McPherson RW: Detection of brachial plexus dysfunction by somatosensory evoked potential monitoring-a report of two cases. Anesthesiology 60: 248-252, 1984

17. McLain RF, Tetzlaff JE, Bell GR, Uwe-Lewandrowski K, Yoon HJ, Rana M: Microdiscectomy: Spinal anesthesia offers optimal results in general patient population. J Surg Orthop Adv Spring 16:5-11, 2007

18. Nicassio N, Bobicchio P, Umari M, Tacconi L: Lumbar microdiscectomy under epidural anaesthesia with the patient in the sitting position: a prospective study. J Clin Neurosci $17: 1537-1540,2010$

19. Ono S, Nishiyama T, Hanaoka K: Hoarseness after endotracheal intubation caused by submucosal hemorrage of the vocal cord and recurrent nerve palsy. Masui 49: 881-883, 2000

20. Papadopoulos EC, Girardi FP, Sama A, Pappou IP, Urban MK, Cammisa FP: Lumbar microdiscectomy under epidural anesthesia: A comparation study. Spine J 6:561-564, 2006

21. Pöpping DM, Elia N, Van Aken HK, Marret E, Schug SA, Kranke $P$, Wenk $M$, Tramèr MR: Impact of epidural analgesia on mortality and morbidity after surgery: Systematic review and meta-analysis of randomized controlled trials. Ann Surg 259(6):1056-1067, 2014

22. Ray CD: New kneeling attachment and cushioned face rest for spinal surgery. Neurosurgery 20: 266-269, 1987

23. Roth S, Tung A, Ksiazek S: Visual loss in a prone-positioned spine surgery patient with the head on a foam headrest and goggles covering the eyes: An old complication with a new mechanism. Anesth Analg 104:1185-1187, 2007

24. Sadrolsadat SH, Mahdavi AR, Moharari RS, Khajavi MR, Khashayar P, Najafi A, Amirjamshidi A: A prospective randomized trial comparing the technique of spinal and general anesthesia for lumbar disk surgery: A study of 100 cases. Surg Neurol 71:60-65, 2009

25. Silver DJ, Dunsmore RH, Dickson CM: Spinal anesthesia for lumbar disc surgery: Review of 576 operations. Anesth Analg 55:550-554, 1976

26. Skipworth J, Srilekha A, Raptis D, O'Callaghan D, Siriwardhana S, Navaratnam R: Combined lumbar spinal and thoracic high-epidural regional anesthesia as an alternative to general anesthesia for high-risk patients undergoing gastrointestinal and colorectal surgery. World J Surg 33:18091814,2009

27. Slabaugh PB, Nickel VL: Complications with use of the Stryker frame. J Bone Joint Surg Am 60:1111-1112, 1978

28. Smith RH: One solution to the problem of the prone position for surgical procedures. Anesth Analg 53: 221-224, 1974

29. Warner MA, Warner ME, Martin JT: Ulnar neuropathy. Incidence, outcome, and risk factors in sedated or anesthetized patients. Anesthesiology 81:1332-1340, 1994

30. Winter R, Munro M: Lingual and buccal nerve neuropathy in a patient in the prone position: A case report. Anesthesiology 71: 452-454, 1989

31. Wolfe SW, Lospinuso MF, Burke SW: Unilateral blindness as a complication of patient positioning for spinal surgery. A case report. Spine 17: 600-605, 1992 